\title{
Guanine and Inosine Nucleotides, Nucleosides and Oxypurines in Snail Muscles as Potential Biomarkers of Fluoride Toxicity*
}

\author{
Monika E. RAĆ, Krzysztof SAFRANOW, Barbara DOŁĘGOWSKA and Zygmunt MACHOY
}

Accepted April 16, 2007

\begin{abstract}
RaĆ M. E., Safranow K., Dołegowska B., Machoy Z. 2007. Guanine and inosine nucleotides, nucleosides and oxypurines in snail muscles as potential biomarkers of fluoride toxicity. Folia biol. (Kraków) 55: 153-160.

The aim of the present study was to determine the toxicity of fluorides on energy metabolism in muscles of the Helix aspersa maxima snail. Qualitative and quantitative analysis of purine compounds was performed in slices of foot from mature snails with high-performance liquid chromatography. Fluoride concentrations were measured using an ion-selective electrode and gas chromatography. The results show that exposure to fluoride pollution was accompanied by a statistically significant increase in fluoride concentrations in soft tissues. This effect was already noticeable with the smallest fluoride dose. Accumulation was greatest in the shell. There is a significant and positive correlation between fluoride concentrations in foot muscles and guanine and inosine nucleotides or uridine content. The content of low-energy guanylate, inosylate and oxypurine in foot muscles significantly increased with rising dose of fluoride. The difference as compared with controls was significant only for the highest dose of fluoride. Interestingly, uric acid, the final product of purine catabolism, dominated quantitatively in the foot muscles of snails. In conclusion, increased low-energy guanylate and inosylate as well as decreased xanthine concentrations in snail muscle can be indicators of the toxic influence of fluoride on the organism. The measuring of fluoride accumulation in the shell is the most suitable bioindicator of fluoride pollution in the environment.
\end{abstract}

Key words: Nucleotides, biomarker, fluoride, snail.

Monika E. RAĆ, Krzysztof SAFRANOW, Barbara DOŁĘGOWSKA, Zygmunt MACHOY, Department of Biochemistry and Medical Chemistry, Pomeranian Medical University, Powstańców Wielkopolskich 72, 70 - 111 Szczecin, Poland.

E-mail: carmon@sci.pam.szczecin.pl

Molluscs are generally recognized as convenient bioindicators of environmental contamination. The toxicity of fluorine to plants, animals and humans has been well documented (MILLER 1997). JĘDRZEJUK and MILEWICZ (1996) have shown that high doses of fluoride in food results in the inhibition of enzymes containing zinc, magnesium or manganese presumably because these metals are bound to and displaced by fluoride. Correlations between the content of fluoride in tissues of snails (Helix pomatia) have been reported. DwOJAK and MACHOY (2000) found correlations between the fluoride level in the environment and in snail shell. Some reports (MACHOY et al. 1995; ZAKRZEWSKA 1995) suggested that exposure of vertebrates to low levels of fluoride results in accumulation of fluoride associated with musculoskeletal symptoms and metabolic disorders. RAĆ
(2005) observed that AMP (adenosine monophosphate $)$ and AEC (adenylate energy charge $)=($ ATP $+\mathrm{ADP} / 2) /(\mathrm{ATP}+\mathrm{ADP}+\mathrm{AMP})$ measured in snail muscle may be used as biomarkers in environmental monitoring. The AMP or AEC value can be an estimate of the condition of the whole organism subjected to the toxic influence of fluoride.

The existing state of knowledge about transformations of purines in snails is presented in Figure 1 and based on RAĆ (2003).

The aim of the present study was to determine the toxicity of fluorides on the energy metabolism in muscles of the snail Helix aspersa maxima. The internal energy status of the cell can be estimated on the basis of measurements of concentrations of guanine and inosine nucleotides (GTP - guanosine triphosphate, GDP - guanosine diphosphate, GMP - guanosine monophosphate, IMP - inosine mono-

* Supported by Polish State Committee for Scientific Research (KBN), grant No. 6P04G 02321. 


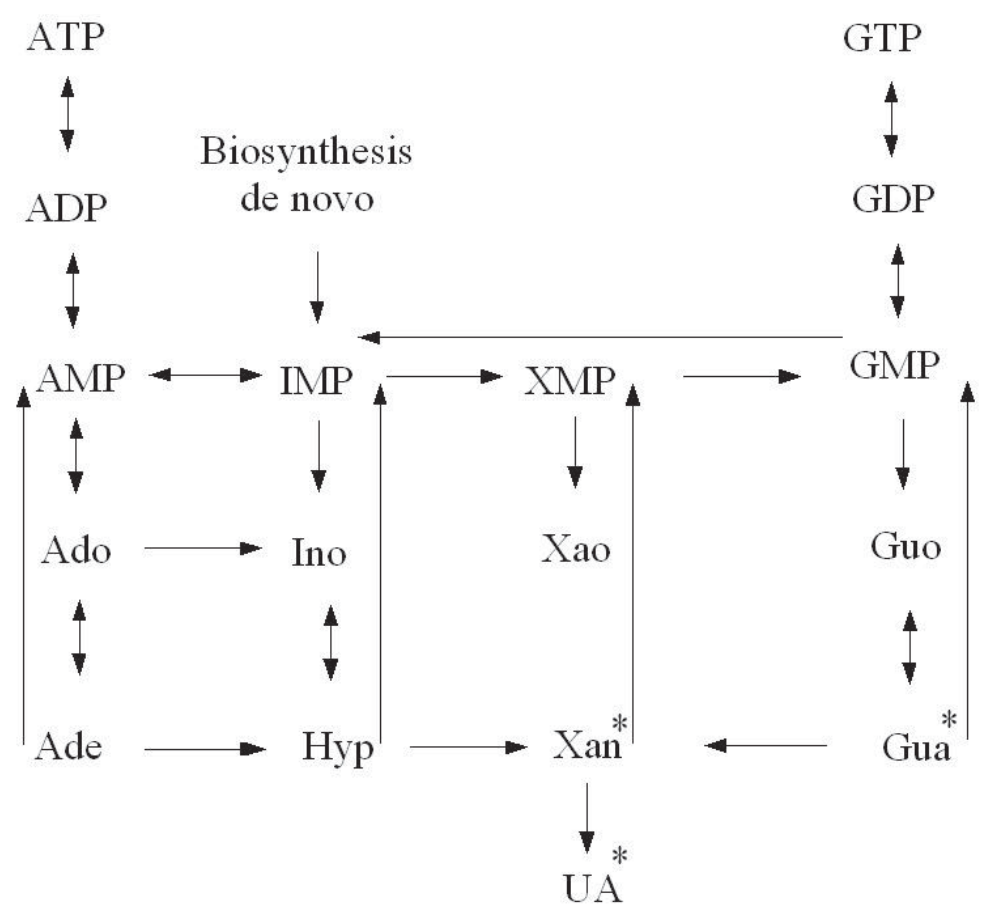

Fig. 1. Diagram of purine metabolism in hepatopancreas of snails (ATP - adenosine triphosphate, ADP - adenosine diphosphate, AMP - adenosine monophosphate, Ado - adenosine, Ade - adenine, IMP - inosine monophosphate, Ino inosine, Hyp - hypoxanthine, XMP - xanthosine monophosphate, Xao - xanthosine, Xan - xanthine, UA - uric acid, GTP guanosine triphosphate, GDP - guanosine diphosphate, GMP - guanosine monophosphate, Guo - guanosine, Gua - guanine). * final products of purine catabolism in snails.

phosphate) and their metabolism degradation products (nucleosides Guo - guanosine and Ino - inosine), oxypurines (Hyp - hypoxanthine, Xan - xanthine, $\mathrm{UA}$ - uric acid) and one pyrimidine nucleoside: Urd - uridine with high-performance liquid chromatography (HPLC). We have chosen a species which is characterized by a high resistance to fluoride pollution (DWOJAK \& MACHOY 2000) and low AEC (DWOJAK et al. 2000) so that fluoride effects on energy metabolism should be visible.

\section{Material and Methods}

The study was performed on Helix aspersa maxima snails removed from aestivation. Snails were given standard pulverized food (recommended by the Institute of Zootechnics in Balice) supplemented with varying doses of sodium fluoride (Table 1). A control culture without fluoride supplementation was run in parallel. Prior to collection of material, the snails were kept without food for 48 hours and then killed by freezing in liquid nitrogen. The experiment was started with 25 snails in each group. Only snails alive at the end of the experiment were used for chemical analysis (a variable number of the sample in Table 1), because a few snails died in each culture group during the experiment. Quantification of fluoride levels was done in soft tissues, foot and hepatopancreas, and also in shells of mature snails. Qualitative and quantitative analyses of purine compounds were performed in slices of foot from mature snails.

Fluoride concentrations in pulverized shells were measured using an ion-selective electrode. Gas chromatography was used to determine fluoride concentrations in the hepatopancreas and foot. Purines were measured in foot muscle slices with high-performance liquid chromatography (HPLC).

Fluoride determinations using an ion-selective electrode were done according to the method of LASSOCIŃSKA et al. (1982) as modified for shells by the authors. Details of this method have been described by RAĆ et al. (2005). The fluoride con-

Table 1

Details of experimental protocol

\begin{tabular}{|c|c|c||}
\hline $\begin{array}{c}\text { Culture group with } \\
\text { number of samples } \\
\text { in 40th day } \\
\text { of the experiment }\end{array}$ & $\begin{array}{c}\text { Concentration } \\
\text { of fluoride ions } \\
\text { in food } \\
\left(\mathrm{mg}^{*} \mathrm{~kg}^{-1}\right)\end{array}$ & $\begin{array}{c}\text { Culture } \\
\text { duration }\end{array}$ \\
\hline \hline $\mathrm{A}_{1}=10$ & control $^{a}$ & \\
\hline $\mathrm{A}_{2}=23$ & 133 & \multirow{2}{*}{ 40 days } \\
\hline $\mathrm{A}_{3}=14$ & 665 & \\
\hline $\mathrm{A}_{4}=22$ & 1330 & \\
\hline
\end{tabular}

${ }^{a}$ concentration in tap water was $0.15 \mathrm{mgF}^{-* \mathrm{l}^{-1}}$ 


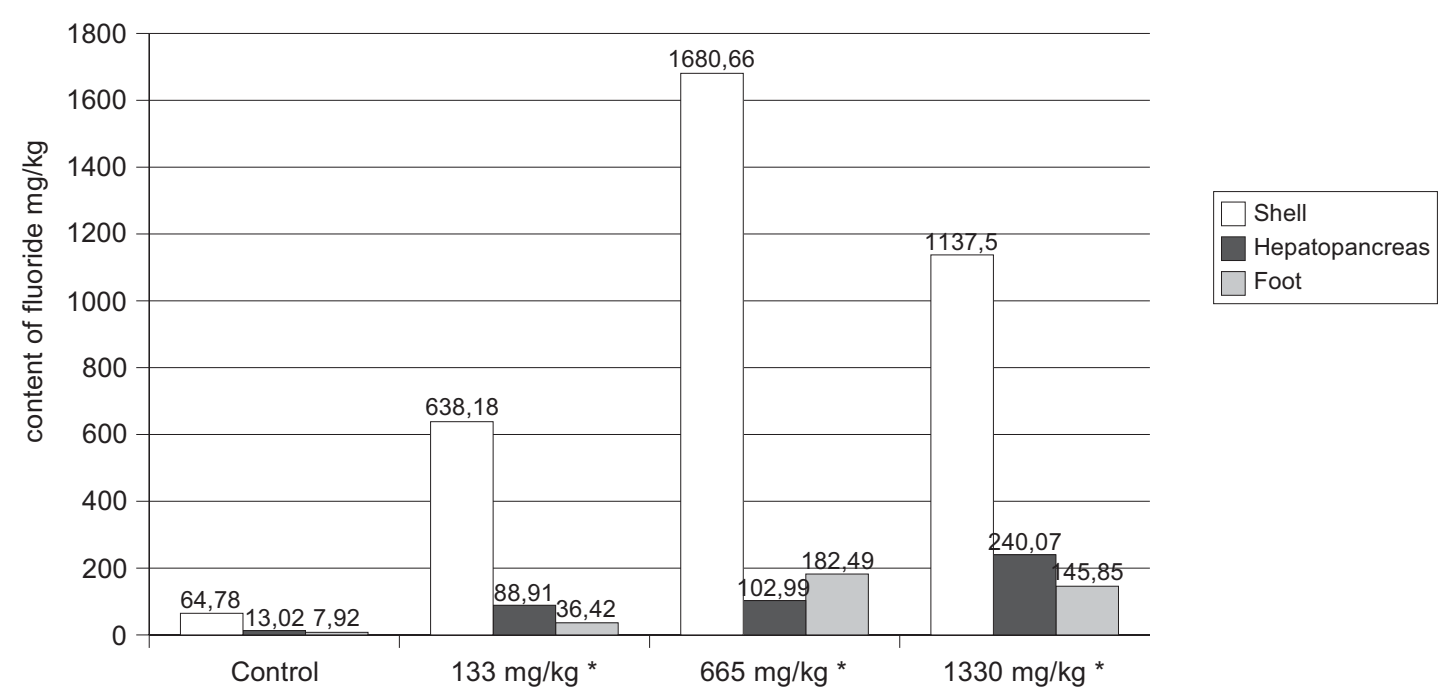

Fig. 2. Content of fluoride $\left[\mathrm{mg} \mathrm{kg}^{-1}\right.$ dry mass] in tissues of Helix aspersa maxima, *level of significance $\mathrm{P}<0.0001$ (Mann-Whitney U-test) as compared with controls (in each tissue).

Table 2

Median (interquartile range) of fluoride concentrations $\left[\mathrm{mg}^{*} \mathrm{~kg}^{-1}\right.$ dry mass $]$ in tissues of $\mathrm{He}$ lix aspersa maxima exposed to rising concentrations of fluoride [ $\mathrm{mg} \mathrm{kg}^{-1}$ food]

\begin{tabular}{|c|c|c|c||}
\hline Fluoride dose $\mathrm{mg}^{*} \mathrm{~kg}^{-1}$ & Shell & Hepatopancreas & Foot \\
\hline \hline \multirow{2}{*}{ Control } & $\begin{array}{c}64.80 \\
(44.19)\end{array}$ & $\begin{array}{c}13.02 \\
(7.44)\end{array}$ \\
\hline \multirow{2}{*}{133} & $\begin{array}{c}638.18^{*} \\
(484.2)\end{array}$ & $\begin{array}{c}88.91 * \\
(1.76)\end{array}$ \\
\hline \multirow{2}{*}{665} & $\begin{array}{c}1680.66^{*} \\
(407.05)\end{array}$ & $102.99 *$ & $36.42^{*}$ \\
& $1137.50^{*}$ & $(84.03)$ & $(10.50)$ \\
\hline \multirow{2}{*}{1330} & $(607.31)$ & $240.07^{*}$ & $182.49^{*}$ \\
& & $(142.05)$ & $145.18)$ \\
\hline
\end{tabular}

*level of significance $\mathrm{P}<0.0001$ (Mann-Whitney U-test) as compared with controls.

centration was read with an OP 262 apparatus (Radelkis, Budapest, Hungary). Quality analysis was checked by measurement of $\mathrm{NaF}$ standard solutions as external standards. Fluoride content was calculated based on the weight of the pulverized sample.

Fluoride measurements using gas chromatography were done according to the method of MIKOEAJEK et al. (1996) with some modifications to account for material specificity. The supernatant was withdrawn and transferred to a CHROM 5 (Laboratorni Pristroje Praha) gas chromatograph equipped with a $2 \mathrm{~m} \mathrm{x} 4 \mathrm{~mm}$ i.d. column filled with $20 \%$ modified silicone oil on Chromosorb P (DC200/50). Oven, injector and FID detector temperatures were $85^{\circ} \mathrm{C}, 220^{\circ} \mathrm{C}$, and $270^{\circ} \mathrm{C}$, respectively. Nitrogen served as a carrier gas flowing at $20 \mathrm{ml} \mathrm{min}^{-1}$. Ali- quots of $1 \mu 1$ were injected every $20 \mathrm{~min}$ and the detector signal was sent to an IBM-PC class computer operating with dedicated software from Medson (Poznań, Poland). Concentrations of fluoride were adjusted for dry mass of sample taken for analysis. Details of this method have been described by RAĆ et al. (2005).

Determinations of purines with highperformance liquid chromatography were carried out according to the validated method of SAFRANOW et al. (2005), modified to account for material specificity. A small fragment was cut off from the foot at maximum contraction, with care to maintain consistency as to size and site of collection. The material was transferred to a $2 \mathrm{ml}$ Eppendorf tube and immediately frozen in liquid 
nitrogen. Samples were next stored at $-80^{\circ} \mathrm{C}$. Prior to analysis the material was placed in a steel mortar with the pestle cooled in liquid nitrogen. Tissues were transferred with a spatula cooled in liquid nitrogen to Eppendorf tubes filled with $500 \mu 10.4 \mathrm{M}$ $\mathrm{HClO}_{4}$ at $0^{\circ} \mathrm{C}$ for protein denaturation, mixed and immediately frozen to $-80{ }^{\circ} \mathrm{C}$. The material was thawed for $15 \mathrm{~s}$ prior to transfer to a rotating blade microhomogenizer. The homogenate was centrifuged at $14000 \mathrm{x} \mathrm{g}$ and $3^{\circ} \mathrm{C}$ for $5 \mathrm{~min}$. The supernatant was neutralized with approximately $100 \mu \mathrm{l}$ $\mathrm{K}_{3} \mathrm{PO}_{4}$ to a $\mathrm{pH}$ of 6-7, placed in a vortex mixer and left for $10 \mathrm{~min}$ at $0^{\circ} \mathrm{C}$. The sediment was centrifuged as described above and the supernatant was kept at $-80^{\circ} \mathrm{C}$. The sediment after the first centrifugation was frozen and used to determine protein content according to BRADFORD (1976). Purines were separated using a Hewlett-Packard series 1050 liquid chromatograph equipped with a quaternary gradient pump with G1322A vacuum degassing module, desalting module, injection valve with a $20 \mu 1$ loop, UV-Vis detector, thermostatted column compartment (series 1100, G1316A type), and an analytical column $150 \mathrm{~mm}$ x $4.6 \mathrm{~mm}$ i.d. containing $3 \mu \mathrm{m}$ Hypersil BDS with $12 \mathrm{~nm}$ pores (Alltech Associates Inc., USA). Details of this method have been described by RAĆ et al. (2005). There are no certified reference materials for purine quantification, so identification and calibration were based on external standards. Quality control was based on a mix of 16 purines, which was chromatographed. The chromatograms were recorded and integrated using an IBM-PC computer with HPLC ChemStation software (Hewlett-Packard, USA). Concentrations were adjusted for protein content of sample.

Statistical analysis was done with Statistica 5.1PL software and non-parametric tests: the Kruskal-Wallis Test, the Mann-Whitney U-Test and the Spearman Rank Correlation Coefficient.

\section{Results}

Concentrations of fluoride in tissues of Helix aspersa maxima are presented in Table 2 and Figure 2. Concentrations of purines in the foot muscle of Helix aspersa maxima are shown in Table 3 and Figure 3. Correlations between purines and fluoride in foot muscle of Helix aspersa maxima for different fluoride doses in food are presented in Figures 4-6.

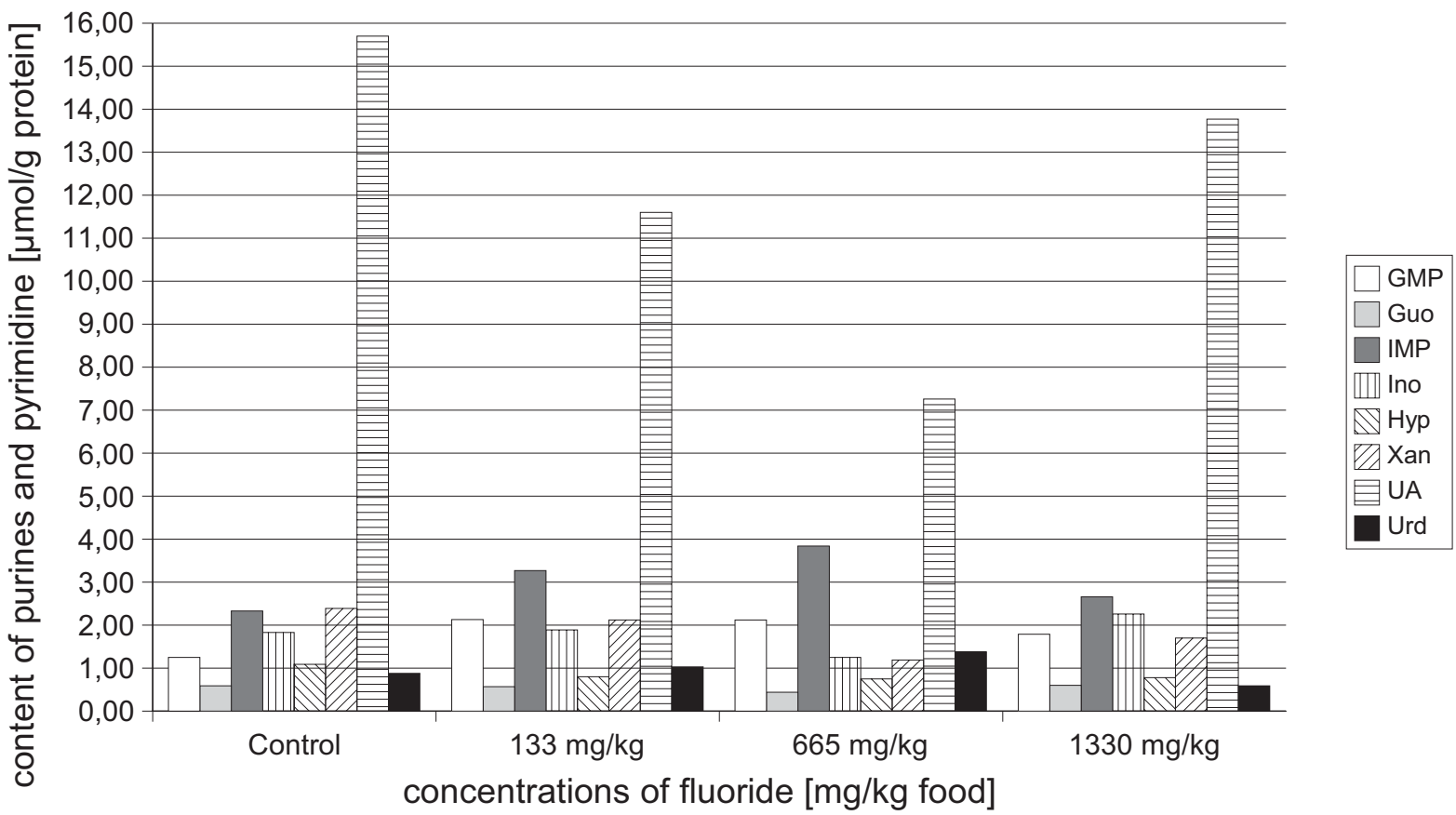

Fig. 3. GMP, Guo, IMP, Ino, Hyp, Xan, UA and Urd content $\left[\mu \mathrm{mol} \mathrm{g}^{-1}\right.$ protein] in foot muscle of Helix aspersa maxima depending on fluoride dose in food (level of significance for differences between all groups $\mathrm{P}<0.05$ for GMP, Guo and Xan Kruskal-Wallis ANOVA). 
Table 3

Median (interquartile range) of purine content $\left[\mu \mathrm{mol} \mathrm{g}^{-1}\right.$ protein $]$ in foot muscles of Helix aspersa maxima exposed to rising concentrations of fluoride [ $\mathrm{mg} \mathrm{kg}^{-1}$ food]

\begin{tabular}{|c|c|c|c|c|c|c|c|c||}
\hline $\begin{array}{c}\text { Fluoride dose } \\
\mathrm{mg} * \mathrm{~kg}^{-1}\end{array}$ & GMP & Guo & IMP & Ino & Hyp & Xan & UA & Urd \\
\hline \hline Control & $\begin{array}{c}1.25 \\
(1.18)\end{array}$ & $\begin{array}{c}0.59 \\
(0.25)\end{array}$ & $\begin{array}{c}2.33 \\
(1.33)\end{array}$ & $\begin{array}{c}1.83 \\
(1.13)\end{array}$ & $\begin{array}{c}1.09 \\
(1.07)\end{array}$ & $\begin{array}{c}2.39 \\
(2.1)\end{array}$ & $\begin{array}{c}15.70 \\
(22.63)\end{array}$ & $\begin{array}{c}0.88 \\
(0.97)\end{array}$ \\
\hline \multirow{2}{*}{133} & $\begin{array}{c}2.13 * \\
(1.35)\end{array}$ & $\begin{array}{c}0.57 \\
(0.36)\end{array}$ & $\begin{array}{c}3.27 \\
(4.13)\end{array}$ & $\begin{array}{c}1.89 \\
(1.42)\end{array}$ & $\begin{array}{c}0.80 \\
(0.67)\end{array}$ & $\begin{array}{c}2.12 \\
(1.25)\end{array}$ & $\begin{array}{c}11.60 \\
(11.02)\end{array}$ & $\begin{array}{c}1.03 \\
(1.69)\end{array}$ \\
\hline \multirow{2}{*}{665} & $\begin{array}{c}2.12 * \\
(0.76)\end{array}$ & $\begin{array}{c}0.44 * * \\
(0.26)\end{array}$ & $\begin{array}{c}3.84 * * \\
(2.31)\end{array}$ & $\begin{array}{c}1.25 \\
(0.67)\end{array}$ & $\begin{array}{c}0.75 \\
(0.33)\end{array}$ & $\begin{array}{c}1.19 * \\
(0.38)\end{array}$ & $\begin{array}{c}7.26 \\
(5.66)\end{array}$ & $\begin{array}{c}1.38 \\
(1.66)\end{array}$ \\
\hline \multirow{2}{*}{1330} & 1.79 & $\begin{array}{c}0.60 \\
(0.84)\end{array}$ & $\begin{array}{c}2.66 \\
(2.50)\end{array}$ & $\begin{array}{c}2.26 \\
(3.71)\end{array}$ & $\begin{array}{c}0.78 \\
(0.66)\end{array}$ & $\begin{array}{c}1.70 \\
(1.0)\end{array}$ & $\begin{array}{c}13.77 \\
(12.31)\end{array}$ & $\begin{array}{c}0.59 \\
(1.07)\end{array}$ \\
\hline
\end{tabular}

*level of significance $\mathrm{P}<0.05$ (Mann-Whitney U-test) as compared with controls **level of significance $\mathrm{P}<0.01$ (Mann-Whitney U-test) as compared with controls.

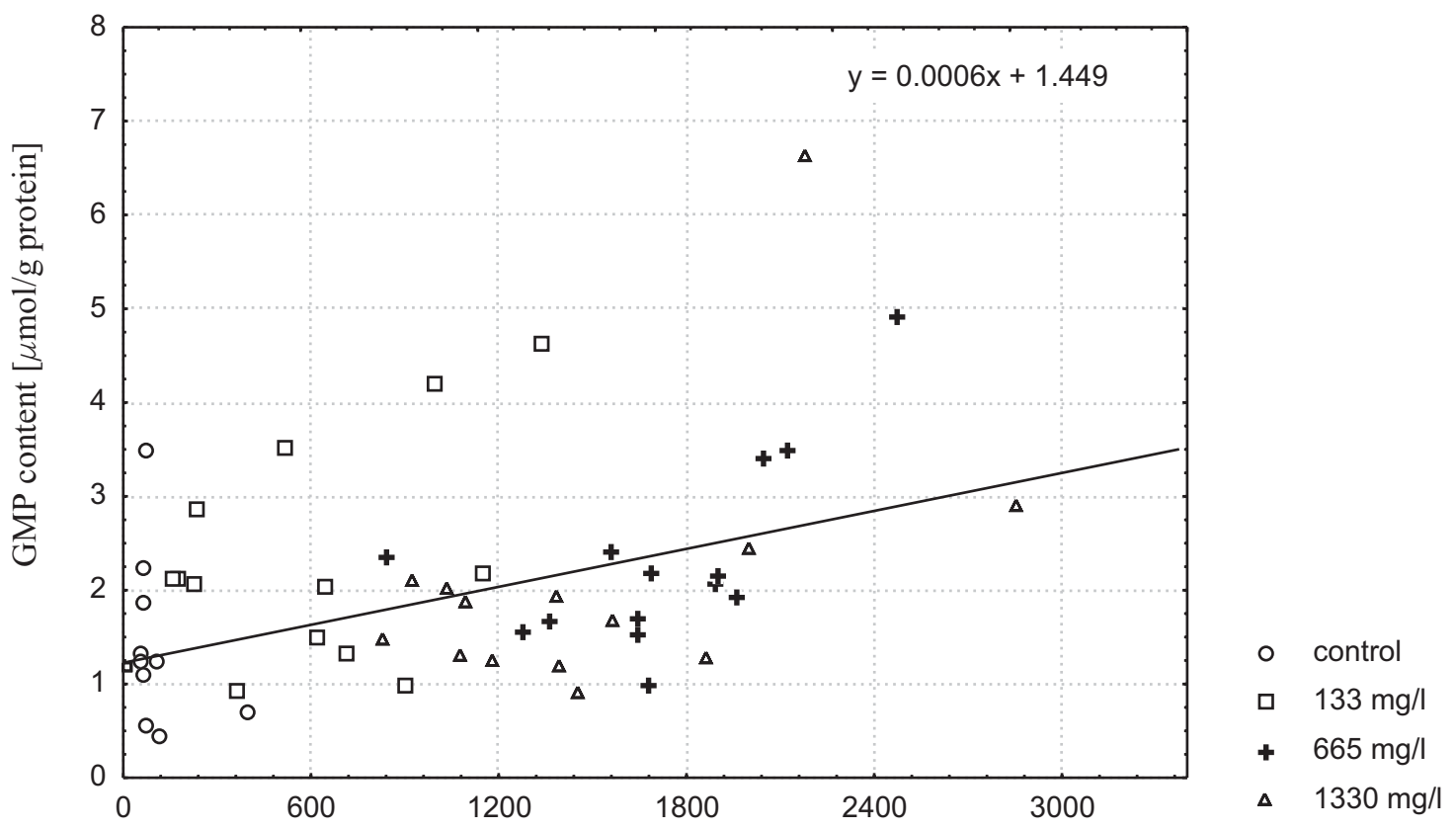

Fluoride content $[\mathrm{mg} / \mathrm{kg}]$ in foot muscles of Helix aspersa maxima

Fig. 4. GMP and fluoride content correlation in foot muscle of Helix aspersa maxima depending on fluoride dose in food (level of significance $\mathrm{P}<0.01$, Spearman rank correlation coefficient +0.34 ).

The results show that exposure to fluoride pollution was accompanied by a statistically significant increase in fluoride concentrations in soft tissues. This effect was already noticeable with the smallest fluoride dose. Accumulation was greatest in the shell (Fig. 2). None of the examined samples was found to contain detectable amounts of GTP and GDP (Table 3, Fig. 3). There is a statistically significant and positive correlation between fluoride concentrations in foot muscles and GMP, IMP and Urd content (Figs 4-6). The content of low-energy guanylate (GMP) and IMP in foot muscles increased significantly with a rising dose of fluoride (Table 3, Figs 3-5). The difference in GMP concentrations as compared with controls was significant for the 133 and $665 \mathrm{mg} / \mathrm{kg} \mathrm{F}$ - doses. Statistically significant differences in IMP concentrations were noted only for the $665 \mathrm{mg} / \mathrm{kg} \mathrm{F}^{-}$dose (Table 3, Figs 3 \& 5). 


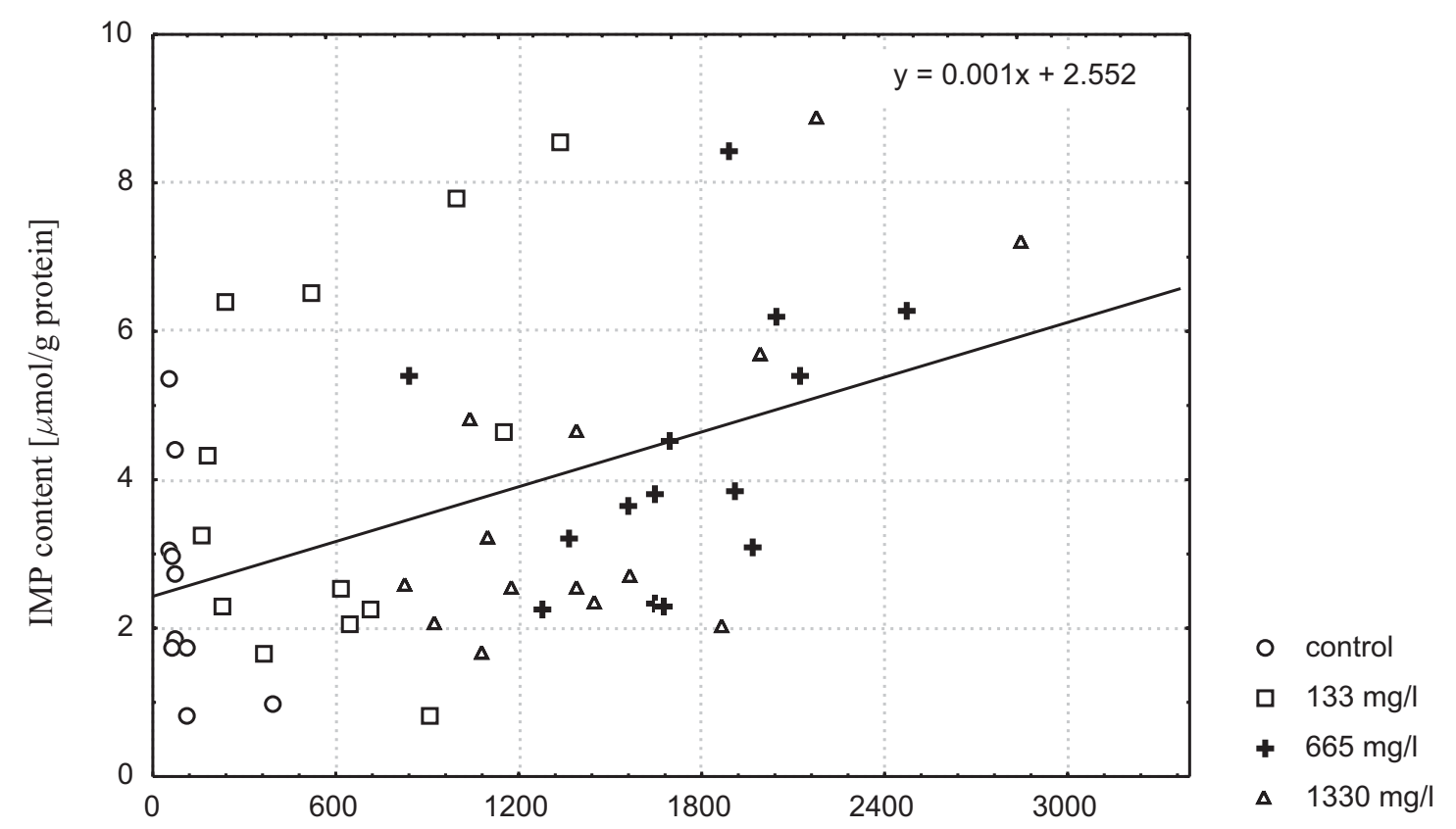

Fluoride content $[\mathrm{mg} / \mathrm{kg}]$ in foot muscle of Helix aspersa maxima

Fig. 5. IMP and fluoride content correlation in foot muscle of Helix aspersa maxima depending on fluoride dose in food (level of significance $\mathrm{P}<0.005$, Spearman rank correlation coefficient +0.34 ).

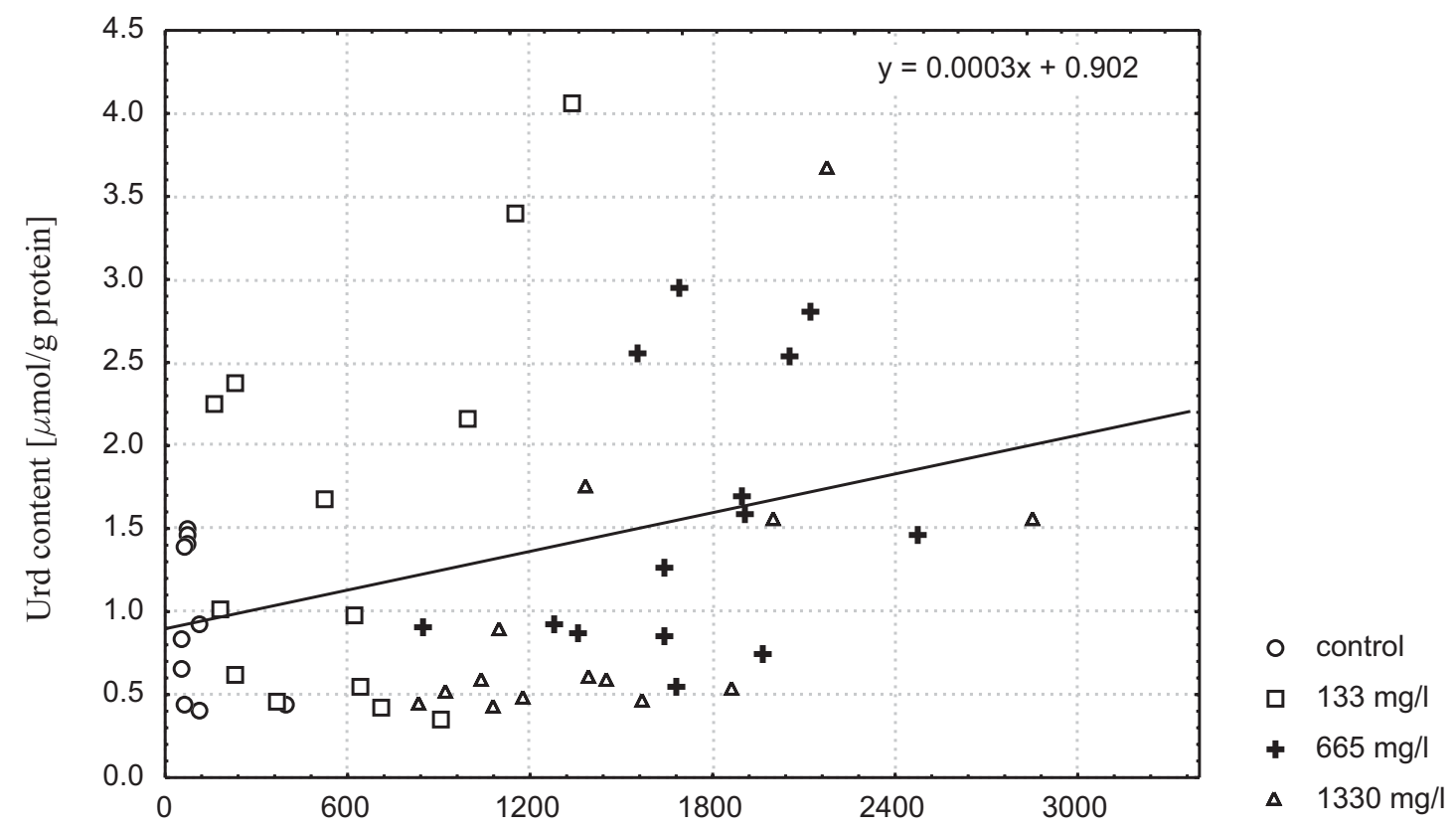

Fluoride content $[\mathrm{mg} / \mathrm{kg}]$ in foot muscle of Helix aspersa maxima

Fig. 6. Urd and fluoride content correlation in foot muscle of Helix aspersa maxima depending on fluoride dose in food (level of signficance $\mathrm{P}<0.05$, Spearman rank correlation coefficient +0.30 ).

When the fluoride dose in food was $665 \mathrm{mg} / \mathrm{kg}$, a decrease in concentrations of nucleoside (Guo) and oxypurine (Xan) in foot muscles were noted (Table 3, Fig. 3). Interestingly, UA, the final product of the purine catabolism, dominated quantitatively in snail foot muscle (Table 3, Fig. 3). The content of Ino, Hyp and UA did not show statistically significant differences between groups (Table 3). 


\section{Discussion}

Using enzymatic techniques other authors (BARANKIEWICZ et al. 1979 and JEŻEWSKA \& SAWICKA 1968) determined the following substances in snail hepatopancreas: Gua, Ino, Xan, UA, AMP, IMP, GTP, ATP, ADP, Urd, Ctd (cytidine). Earlier reports (RAĆ et al. 2002) suggested that concentrations of purine indicators of the energy metabolism differ significantly in life and seasonal cycles. The most modern method of HPLC used in the present work identified the following purine derivatives in snail foot muscles, in the sequence of decreasing mean concentration: UA, IMP, Xan, Ino, GMP, Hyp, Urd, Guo. Despite using such a sensitive method, none of the examined samples was found to contain detectable amounts of GTP or GDP. The presented method could not resolve Gua, XMP and Xao.

Until now there are no publications about the influence of fluoride on the guanine and inosine nucleotides, nucleosides and oxypurines in snail muscles. In this work statistically significant differences in energy metabolism could be observed for the $665 \mathrm{mg} / \mathrm{kg} \mathrm{F}^{-}$dose, except for GMP levels in the foot which were elevated starting from the lowest concentration of fluoride used. None of the examined samples was found to contain detectable amounts of GTP or GDP, identified by other authors (DETERRE 1983). Similarly it was confirmed in previous studies (RAĆ 2003; RAĆ et al. 2005 ) that rising concentrations of fluoride lead to increased levels of AMP accompanied by an insignificant decrease in ATP and ADP levels. As a result, AEC was reduced in parallel to rising exposure to fluoride. Thus, a high fluoride concentration probably inhibits oxidative phosphorylation. Studies by DICKSON and GIESY (1982) have revealed that changes in AEC values in animal tissues are considered to reflect natural, as well as anthropogenic, transformations in the environment to a much greater extent than changes in concentrations of adenine nucleotides. Our earlier report (RAĆ et al. 2005) suggested that in cases of high levels of fluoride it seems reasonable to measure the content of AMP or the value of AEC which appear to serve as universal indicators of depressed metabolic function. In this work a positive correlation between fluoride concentrations in foot muscles and GMP seems to indicate that GMP measurement in snail muscle can be more suited as an estimate of the condition of the whole organism exposed to toxic fluoride.

VoGEL and OTTOW (1991) observed that tissue concentrations of fluoride in snails depend on the distance from the pollution emitter and that these molluscs are capable of achieving tissue levels between 207 and $808 \mu \mathrm{g} \mathrm{g}^{-1}$ with maximum concen- trations in the intestines and shell and minimum in reproductive organs. The results of this study indicate that there is significant accumulation of fluoride in soft tissues of snails. During chronic exposure to fluoride, the process of accumulation was most evident in the shell. Accumulation in the shell was significantly increased with the lowest concentration of fluoride with levels above those in the foot or hepatopancreas.

In conclusion, increased GMP and IMP as well as decreased Xan concentrations in snail muscle can be used as indicators of the toxic influence of fluoride on the condition of the whole organism. GMP measurement in snail muscle is the most suitable indicator of depressed metabolic function. Measurement of fluoride accumulation in the shell is the most suitable bioindicator of fluoride pollution in the environment.

\section{References}

BARANKIEWICZ J., KADŁUBOWSKA H., JEŻEWSKA M. M. 1979. Adenine cycle in hepatopancreocytes of Helix pomatia (Gastropoda). Acta Biochim. Pol. 26: 11-19.

BRADFORD M. M. 1976. A rapid and sensitive method for the quantitation of microgram quantities of protein utilizing the principle of protein-dye binding. Anal. Biochem. 72: 248-254.

Deterre P., GOZlan H., BOCKAERT J. 1983. GTPdependent anion-sensitive adenylate cyclase in snail ganglia potentiation of neurotransmitter effects. J. Biol. Chem. 258: 1467-1473.

DICKSON G. W., GIESY J. P. 1982. The effects of starvation on muscle phosphoadenylate concentrations and adenylate energy charge of surface and cave crayfish. Comp. Biochem. Physiol. A. 71: 357-361.

DWOJAK M., MACHOY Z. 2000. Circulation of fluorides in the life cycle of the edible snail Helix aspersa maxima. Fluoride 33: S3-S4.

DWOJAK M., SAFRANOW K., MACHOY Z. 2000. The effect of fluorides on the energy balance of Helix aspersa maxima, based on analysis of purine derivatives in soft parts. Folia Malacologica 8: 288.

JEŻEWSKA M. M., SAWICKA T. 1968. The presence of uric acid, xanthine and guanine in the haemolymph of the snail Helix pomatia (Gastropoda). Bull. Acad. Pol. Sci. 16: 197-201.

JĘDRZEJUK D., MILEWICZ A. 1996. Fluoride toxicology. Bromat. Chem. Toxicol. 3: 89-96.

LASSOCIŃSKA A., CHMIELEWSKI K., DOMAŻALSKA E. 1982. Evaluation of fluorine determinability in biological material by means of ionoselective fluorine electrode. Metabolizm Fluoru 2: 22-25.

Machoy Z., DĄBKowska E., SAmujŁo D., OGOŃSKi T., RACZYŃSKI J., GĘBCZYŃSKA Z. 1995. Relationship between fluoride content in bones and the age in European elk (Alces alces L.). Comp. Biochem. Physiol., Part C. 111: $117-120$.

MikołaJEK W., JAKuBOWSKA K., OGOŃSKi T. 1996. Estimation of fluoride content in kidneys of rats exposed to fluorine influence by digestive or respiratory tracts. Metabolizm Fluoru 7: 72-75.

MiLLER G. W. 1997. Fluoride: a toxic substance. Fluoride 30: 141. 
RAĆ M., SAFRANOW K., MACHOY Z. 2002. The content of purine nucleotides in the life cycle and winter numbness state in snail Helix aspersa maxima. Pol. J. Natur. Sci. 10: 239-248.

RAĆ M. E. 2003. The influence of some trace elements on bioaccumulation in tissues and bioenergetic metabolism of the edible snail Helix aspersa maxima as determined by HPLC of purine derivatives. Ann. Acad. Med. Stetinensis 49: 63-77.

RaĆ M., SAFranow K., Jakubowska K., ChlubeK D. MACHOY Z. 2005. Adenine nucleotides in snail muscles as one of biomarkers of fluoride toxicity. J. Environ. Monit. 7: 631-634.
SAFRANOW K., RZEUSKIR., LISTEWNIK M. J., JAKUBOWSKAK RAC M. E., OLSZEWSKA M., CHLUBEK D. 2005. Myocardial and coronary sinus purines as indicators of pig heart energy metabolism during reperfusion after extracorporeal circulation. Acta Physiol. Scand. 185: 13-23.

Vogel J., OtTow J. C. G. 1991. Fluoride loads of terrestrial gastropods near a source of emission. Oecologia 19: 177-182.

ZAKRZEWSKA H. 1995. Fluorine and its compounds in the environment and food. Bromat. Chem. Toxicol. 28: 393-398. 